\title{
The Empirical Analysis of China's Industrial Structure Optimization Based on Resources and Environment Constraints
}

\author{
Ning Guoyu \\ School of Economics and Management, \\ Northwest University,229 Taibai N. Rd.Xi'an, \\ Shaanxi,China710069
}

\author{
Zhao Jingfeng \\ School of Economics and Management, \\ Northwest University,229 Taibai N. Rd.Xi'an, \\ Shaanxi,China710069
}

\begin{abstract}
Currently, China's industrial structure optimization is facing increasingly serious resources and environment constraints, especially the consumption of resources and the ecological environment pressure increasing, economic development potential is clearly insufficient. So, in this paper, bulid a planning model of three objective function of covers economic growth, resource conservation, pollution control, as the constraint of energy conservation and emissions reduction, to analysis China's 2013-2015 data, especially with gray prediction method to comprehensive forecast of 2015 emissions. In order to optimize the industrial structure to realize breakthrough provide certain reference resources and environment constraints, in order to help achieve steady and healthy development of national economy development.Trying to through the optimization of industrial structure provide certain reference to break through the resources and environment constraints, in order to help achieve steady and healthy development of national economy.
\end{abstract}

Keywords-Environment Constraints ; Industrial Optimization; Model Design, Grey Prediction ; objective functions; model

\section{INTRODUCTION}

The industrial structure is an important bond of economic activities and ecological environment, and the industrial structure is closely related to the economic growth, resource utilization, and environmental pollution. Therefore, the industrial structure optimization refers to the quality and sustainability of the economic growth. During the process of the economic growth, the contradiction between the limitation of the natural resource supply and the ever-increasing demands, between the limited bearing capacity of the environment and the increasing pollutant discharge are sharpening day by day. For example, at present the structural contradictions of the industry in China is acute, and the high energy-consuming industry has relatively large energy consumption. The comprehensive energy consumption of the industry above designated size has rapid growth, and the energy use efficiency is low, and the outdated capacity exit mechanism is unsound, resulting in the unsustainability of the energy resource consumption. Especially under the multiple stresses and restrictions of the scarce resources, energy shortage, and environmental pollution, exploring the industrial structure optimization problems under the dual constraints of the resource and environment possesses the major theoretical and practical significance, so as to provide the favorable development opportunity for the industrial structure optimization under the dual constraints of the resource and environment.

\section{MODEL DESIGN OF INDUSTRIAL STRUCTURE OPTIMIZATION UNDER RESOURCE AND ENVIRONMENT CONSTRAINTS )}

\section{A. Building objective functions}

In combination with the special national conditions, this paper designs the objective functions in three aspects, involving economic growth, resource consumption and pollution control. The ultimate goal of the industrial structure optimization is to achieve the growth of the gross national product and adopt GDP maximum as one of the optimization objectives. Under the resource and environment constraints, the industrial water consumption and industrial energy consumption per ten thousand yuan of GDP is the major indicator of investigating the industrial water efficiency and energy consumption efficiency. Thus, the minimum total water consumption and high energy consumption efficiency is another major indicator of optimization. The discharge of three wastes is also the major indicator of measuring the pollutant discharge of the industrial department. Reducing the total discharge of three wastes is of great significance for relieving the ecological environment stress. follows:

The objective functions of the model are built as

\section{1) Economic growth objective} $\operatorname{maxF}\left(\mathrm{x}_{\mathrm{t}}\right)=\sum \mathrm{a}_{\mathrm{i}}^{*} \mathrm{x}_{\mathrm{i}}(\mathrm{t})$

It regards achieving the economic growth maximum as the objective. $a_{i}$ is the value-added rate of the industry, and $\mathrm{x}_{\mathrm{i}}(\mathrm{t})$ is the total output value of the $\mathrm{i}$ industry at $\mathrm{t}$ phase.

2) Resource consumption control objective $\min \mathrm{G}\left(\mathrm{x}_{\mathrm{t}}\right)=\sum \mathrm{c}_{\mathrm{i}}(\mathrm{t}) * \mathrm{x}_{\mathrm{i}}(\mathrm{t}) ; \min \mathrm{H}\left(\mathrm{x}_{\mathrm{t}}\right)=\sum \mathrm{d}_{\mathrm{i}}(\mathrm{t}) * \mathrm{x}_{\mathrm{i}}(\mathrm{t})$

It regards the resource consumption minimum as the objective, to achieve the minimum industrial energy consumption per ten thousand yuan of GDP and minimum industrial water consumption. $\mathrm{c}_{\mathrm{i}}(\mathrm{t})$ is the gross output energy consumption coefficient of each establishment at $t$ phase. $\mathrm{d}_{\mathrm{i}}(\mathrm{t})$ is the gross output water consumption coefficient of each establishment at $t$ phase. 


\section{3) Pollution control objective} $\min K\left(\mathrm{x}_{\mathrm{t}}\right)=\sum \mathrm{e}_{\mathrm{i}}(\mathrm{t}) * \mathrm{x}_{\mathrm{i}}(\mathrm{t})+\sum \mathrm{f}_{\mathrm{i}}(\mathrm{t}) * \mathrm{x}_{\mathrm{i}}(\mathrm{t})$

It regards the pollution minimum as the objective, to represent by the minimum chemical oxygen demand and sulfur dioxide emission in reference to the relevant literatures. In the formula, $\mathrm{e}_{\mathrm{i}}(\mathrm{t})$ is the chemical oxygen demand emission coefficient of the $\mathrm{i}$ industry in t year. $\mathrm{f}_{\mathrm{i}}(\mathrm{t})$ is the sulfur dioxide emission coefficient of the $i$ industry in $\mathrm{t}$ year.

\section{B. Determination of constraint conditions}

\section{1) Constraint of industrial scale}

Control the scale of the industrial development in accordance with the industrial development planning and industrial growth laws.

Constraint of energy sources

$$
\sum \mathrm{c}_{\mathrm{i}}(\mathrm{t}) * \mathrm{x}_{\mathrm{i}}(\mathrm{t})<=\mathrm{R}_{1}(\mathrm{t})
$$

$\mathrm{R}_{1}(\mathrm{t})$ is the constraint of the maximum energy consumption of each industry in $t$ year.

Constraint of water resources

$\sum \mathrm{d}_{\mathrm{i}}(\mathrm{t}) * \mathrm{x}_{\mathrm{i}}(\mathrm{t})<=\mathrm{R}_{2}(\mathrm{t})$

$\mathrm{R}_{2}(\mathrm{t})$ is the constraint of the maximum water consumption of each industry in t year.

\section{2) Constraint of pollution control}

(1) Constraint of chemical oxygen demand

$\sum \mathrm{f}_{\mathrm{i}}(\mathrm{t}) * \mathrm{x}_{\mathrm{i}}(\mathrm{t})<=\mathrm{R}_{3}(\mathrm{t})$

$\mathrm{R}_{3}(\mathrm{t})$ is the constraint of total chemical oxygen demand emission of waste water discharge represented by each industry in $t$ year.

(2) Constraint of sulfur dioxide emission $\sum \mathrm{e}_{\mathrm{i}}(\mathrm{t}) * \mathrm{x}_{\mathrm{i}}(\mathrm{t})<=\mathrm{R}_{4}(\mathrm{t})$

$\mathrm{R}_{4}(\mathrm{t})$ is the constraint of total sulfur dioxide emission of waste water discharge represented by each industry in $t$ year.

\section{Determination of output department}

The data as required by the model is mainly calculated on basis of China Statistical Yearbook (20122013), and Environmental Statistical Bulletin of China (2012-2013). Based on the industrial structure optimization model with goal of resource saving and environmental protection built above, it lays extra emphasis on estimating the industrial energy consumption, water consumption, pollution discharge and industrial structure proportional relation from 2014 to 2015 in China. Due to the difference of the data statistical caliber and the difficulty level of the data collection, it finally determines three industries of China as the optimization objective. During the solution process of the model, the determination of the initial data and parameters is the key factor, which will directly influence the estimation result. Thus, it is necessary to firstly determine these parameters.

\section{Determination of parameters}

Determination of parameters in plan summary. The production value structure change evaluation of China is mainly in accordance with The Twelfth Five-year Plan Summary of National Economic and Social Development. During the period of "the Twelfth Five-year Plan", the average annual increase of the gross domestic product is more than $7 \%$. The industrial structure tends to become more reasonable, and the development quality and level of three industries are improved significantly. The average annual increase of the added value of the service industry is more than 4\%. According to the decomposition indicators of the energy saving and emission reduction in Comprehensive Work Program of Energy Saving and Emission Reduction in The Twelfth Five-year Plan by the State Council, the energy consumption per ten thousand yuan of GDP is reduced by $16 \%$, for the purpose of determining the dynamic control objective of the energy constraint. The specific parameters are shown in Table 1.

TABLE I. TABLE 1 DETERMINATION OF OPTIMIZATION MODEL R VALUE

\begin{tabular}{|c|c|c|}
\hline $\begin{array}{c}\text { Determination of } \mathbf{R} \\
\text { Value }\end{array}$ & 2013 & Remarks \\
\hline $\begin{array}{l}\text { Energy consumption } \\
\text { per ten thousand } \\
\text { yuan of GDP (ton } \\
\text { standard coal) }\end{array}$ & {$[0,1.926]$} & $\begin{array}{l}\text { The energy consumption per } \\
\text { ten thousand yuan of GDP is } \\
\text { reduced by } 10 \% \text { in "the } \\
\text { Twelfth Five-year Plan". }\end{array}$ \\
\hline $\begin{array}{l}\text { The water } \\
\text { consumption of the } \\
\text { primary industry } \\
(100 \text { million cubic } \\
\text { meters) }\end{array}$ & {$[0,495.95]$} & $\begin{array}{l}\text { The total water consumption } \\
\text { ratio of the primary industry } \\
\text { is reduced by } 4 \% \text { in "the } \\
\text { Twelfth Five-year Plan". }\end{array}$ \\
\hline $\begin{array}{l}\text { The water } \\
\text { consumption of the } \\
\text { secondary industry } \\
(100 \text { million cubic } \\
\text { meters) }\end{array}$ & {$[13.6,14.14]$} & $\begin{array}{l}\text { The water saving of the } \\
\text { primary industry is fully used } \\
\text { for determining the maximum } \\
\text { limit of the secondary } \\
\text { industry. }\end{array}$ \\
\hline $\begin{array}{l}\text { The water } \\
\text { consumption of the } \\
\text { tertiary industry } \\
(100 \text { million cubic } \\
\text { meters) }\end{array}$ & {$[1.14,1.19]$} & $\begin{array}{l}\text { The water saving of the } \\
\text { primary industry is fully used } \\
\text { for determining the maximum } \\
\text { limit of the tertiary industry. }\end{array}$ \\
\hline $\begin{array}{l}\text { Chemical oxygen } \\
\text { demand emission } \\
(10 \text { thousand tons) }\end{array}$ & {$[0,56.9]$} & $\begin{array}{l}\text { The emission of "the Twelfth } \\
\text { Five-year Plan" is controlled } \\
\text { within the scope of "the } \\
\text { Eleventh Five-year Plan". }\end{array}$ \\
\hline 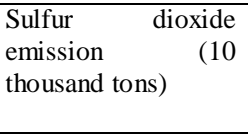 & {$[0,63.1]$} & $\begin{array}{l}\text { The emission of "the Twelfth } \\
\text { Five-year Plan" is controlled } \\
\text { within the scope of "the } \\
\text { Eleventh Five-year Plan". }\end{array}$ \\
\hline
\end{tabular}

Grey prediction. It is a system science theory initiated by Professor Julong Deng as the scholar of China in 1980s. It includes five types of the prediction methods, and the foundation of the sequence prediction is based on the GM $(1,1)$ model of the accumulated generating sequence. The method is used for the prediction of the parameter coefficient.

\section{III. ANALYSIS ON ENERGY SAVING AND EMISSION REDUCTION PROGRAM OF INDUSTRIAL STRUCTURE OPTIMIZATION IN CHINA BASED ON ENERGY SAVING AND EMISSION REDUCTION}

The industrial structure optimization of China under the resource and environment constraint should achieve the economic growth maximum and also achieve multiple objectives such as the improvement of the resource consumption efficiency and the controlling of the pollution discharge. Moreover, the energy saving and emission reduction program is the optimization program with the energy saving, less environmental pollution, ecological environmental protection, and improvement of self-healing capacity of the environment as the primary objective, giving consideration to the economic growth. Therefore, this paper make the optimization analysis on the industrial structure through designing the single objective of the 
energy saving and emission reduction. According to the requirements and the constraint conditions of the energy saving and emission reduction in China, in consideration to the threshold value of the industrial energy consumption per ten thousand yuan of GDP and pollution discharge, it utilizes the calculation method set out above. According to the dynamic adjustment of the planning year, the optimization results of three industries are obtained, as shown in Table 2.

In the energy saving and emission reduction program, in order to meet the requirements of the energy saving and the total emission reduction of the chemical oxygen demand and the sulfur dioxide, the industries with more energy consumptions involving petroleum processing, coking, chemical industry, steel and electric power in Xinjiang should strengthen the technical innovation, make great efforts to enhance the energy use efficiency. The environmental pollution control of the program sacrifices the economic growth to a certain extent. The total output value in this program can not reach the increase level of total output value in the economic growth program. In the program, total quantity of GDP in 2015 will be RMB $57,740.9$ billion, which is lower than the total output value level achieved under the scheme of the economic growth. In addition, from the production value structure, the proportion of the primary industry is relatively small, and the contribution of the secondary industry to the economic growth is declined slightly, which shows that the secondary industry of China plays a larger role in the economic growth. The contribution of the tertiary industry to the economic growth has relatively large ascending range, indicating that the energetic development of the tertiary industry is beneficial to the pollution control. At the same time, only upon considering the increase of the ecological environment cost, the quality of the economic growth can be achieved finally.

TABLE II. TABLE 2 INDUSTRIAL STRUCTURE OPTIMIZATION RESULT OF ENERGY SAVING AND EMISSION REDUCTION

\begin{tabular}{l|l|l}
\hline & $\mathbf{2 0 1 4}$ & $\mathbf{2 0 1 5}$ \\
\hline $\begin{array}{l}\text { Energy consumption (10 thousand ton } \\
\text { standard coal) }\end{array}$ & 37.9 & 38.1 \\
\hline $\begin{array}{l}\text { Energy saving and water consumption } \\
(100 \text { million cubic meters) }\end{array}$ & 121 & 119 \\
\hline $\begin{array}{l}\text { Chemical oxygen demand emission for } \\
\text { emission reduction (10 thousand tons) }\end{array}$ & 2326 & 2238 \\
\hline Sulfur oxide emission (10 thousand tons) & 2007 & 1999 \\
\hline $\begin{array}{l}\text { The proportion of the primary industry } \\
(\%)\end{array}$ & 9.8 & 9.7 \\
\hline $\begin{array}{l}\text { The proportion of the secondary industry } \\
(\%)\end{array}$ & 44.1 & 44.0 \\
\hline The proportion of the tertiary industry $(\%)$ & 46.1 & 46.3 \\
\hline Total output value (100 million yuan) & 573111 & 577409 \\
\hline
\end{tabular}

\section{CONCLUSIONS}

In the $21^{\text {st }}$ century, the pace for the economic globalization and regional economic integration is quickening, and various countries in the world begin to a new round of the industrial structure upgrading and adjustment, and the industrial structure is faced with the tasks of upgrading and seniorization. In the course of the economic development in China, the industrial structure is not completely reasonable, and the energy and resource use efficiency is low, and the ecological environment is weak. Adjusting and optimizing the industrial structure timely and walking on the path of the sustainable development shall be the inevitable course of realizing the transformation of the economic development mode and breaking through the "bottleneck" restraint of the resource and environment. Therefore, it is necessary to implement the sustainable development strategy, and strive to achieve the harmony in two aspects, i.e. on the one hand, it is necessary to seek the balance among promoting the industrial development, saving resources, and protecting the environment. On the other hand, through perfecting the social security system continuously, persist in achieving the harmony between the economic social development and the population resource and environment for the industry, so as to create the favorable conditions for the sustainable, rapid and stable development of the economy constantly.

\section{REFERENCES}

[1] [1] Yue Dai. Research on Industrial Structure Optimization under Resource and Environment Constraint [J]. Academic Exchange, 2014 (2): 126-129

[2] [2] Xian Dong. Multi-objective Dynamic Random Optimization Model of Industrial Structure of China [D]. Dalian University of Technology, 2008.

[3] [3] Qing Chen. Research on Multi-objective Optimization of Industrial Structure Adjustment in Wuhan City under Environment and Resource Constraint [D]. Huazhong University of Science and Technology, 2011.

[4] [4] Fang Li. Multi-objective Model Building and Empirical Research of Industrial Structure Optimization in Xinjiang under Resource and Environment Constraint $[\mathrm{J}]$. Xinjiang Farms Economy, 2013 (7): 39-43

[5] [5] Chang Meng. Review of Industrial Structure Research Progress - Orientation of Regional Industrial Structure Research under Resource and Environment Constraint [J]. Modern Finance and Economics, 2012 (1): 97-104

[6] [6] B hringer,C,U Moslener,U.Oberndorfer,A.Ziegler.Clean and Productive?Empirical Evidence from the German Manufacturing Industry[M]. Research Policy . 2012

[7] [7] Xiang song Ye, Liangyan Peng. Regulatory efficiency of environmental regulation and total factor productivity under study:.1999-2008 [J]. Finance and Trade Economics. 2011 (2): $102-109+137$

[8] [8] KuosmanenTimo,Neil Bijsterbosch,Rob Dellink.Environmental Cost-Benefit Analysis of Alternative Timing Strategies inGreenhouse Gas Abatement:AData Envelopment Analysis Approach[D]. Ecological Economics . 2009

[9] [9] Berman E,Bui L.T.Environmental Regulation and Productivity:Evidence from Oil Refineries. The Review of Economics and Statistic . 2001

[10] [10] Yijun Yuan and LiuLiu.Environmental Regulation and Economic Growth:A Research Based on Different Kinds of Economic Regulation[J]. Economic Review 2013(1) :27-33

[11] [11] Kumar Surender.Environmentally Sensitive Productivity Growth:AGlobal Analysis Using Malmquist-Luenberger Index[M]. Ecological Economics . 2006

[12] [12] Pargal,S,Wheeler,D.Informal Regulation of Industrial Pollution in Developing Countries:Evidence from Indonesia[D]. Policy Research Working PaperNo.1416. 1995

[13] [13] Berman E,Bui L.T.Environmental Regulation and Productivity:Evidence from Oil Refineries[D].The Review of Economics and Statistic . 2001

[14] [14] Benjamin E Blair,Diane Hite.The Impact of Environmental Regulations on the Industry Structure of Landfills[M]. Growth and Change . 2005

[15] [15] Hui Shuang He.Environmental quality, environmental regulation and industry structure optimization-Empirical Analysis Based on China's east, central and western Panel Data [J] .2015 (1): 105-110. 